\title{
Anthony Pym 2012. On Translator Ethics. Translated by Heike Walker. Revised by the author. Amsterdam/Philadelphia: John Benjamins Translation Library. ISBN 978-90-272-2454-5
}

Anthony Pym's book On Translator Ethics is a translation (by Heike Walker) of the French original which was published in 1997. In the English language version Pym not only reworks some of the talks that he gave eighteen years earlier at the Collège International de Philosophie in Paris, founded, among others, by Jacques Derrida, but he has also included an afterword as well as an update in six of the seven chapters comprising the book.

As quite a few of the ideas presented in the book have been previously published in individual articles in various publications by the prolific author (see XII), some of the contents might be already familiar to the reader. Although the book mostly deals with ethical issues connected to people - translation scholars, translators as well as historic characters, who, by the way, are unexpectedly not all translators or translating agents, and one German neo-Nazi to top it all - it does not constitute a comprehensive account of translator ethics. Nor does it aim to do that. Instead, it is the author's own postulate of such ethics based on the review and criticism of some classic philosophical works and the writings of certain prominent Translation Studies scholars.

In short, the author argues that translators as in-betweens and messengers are located in a specific intercultural space. In this imaginary space between cultures their function and highest ethical goal is to facilitate, benevolently and impartially, intercultural cooperation. Unlike Homi Bhabha's Third Space, which is full of tension and conflict, Pym's space in-between seems to be largely free of such nasty aspects. (See also Koskinen 2000: 70-71.) Granted, Pym has added a footnote (3) on page 10 of the English version defending himself against such criticism, but it is, nevertheless, up to the reader, after having read the entire book, to construct their interpretation of the matter. Anyhow, the occupants of the space in-between, also called intercultural mediators, consist of professional translators, Blendlinge (here defined differently from Schleiermacher, 3032 ), or endearingly "bloody fine bastards" (21-23), and, in this day and age of crowdsourcing, also of anyone who translates, for whatever reason, whether economic or symbolic, or just for fun (4, 81-86). As a result, the author claims: "translator ethics now has to consider rather more than the professional translator" (84).

The aim of the book is not to ask the all too familiar, dualistic question in Translation Studies which is rightly, and quite sharply, criticized by the author - of how one should translate. Instead, the author suggests that we posit another ethical question altogether: why translate (6-9)? However, before deciding whether to translate or not, the translator should ask yet another question: in exchange for what (7), all the while keeping in mind the overarching ethical aim of translating, which is to promote cooperation.

The book approaches its subject from various perspectives, as outlined in the chapter headings: In-betweens, Messengers, Professionals?, Interveners, Missionaries, and Agents of cooperation. The $7^{\text {th }}$ chapter, then, summarises Pym's five principles for translator ethics: 1) Translators are responsible for their product as soon as they accept to produce it. 2) Translators are responsible for the probable effects of their translations. 3) Translator ethics need not involve deciding between two cultures. 4) Transaction costs should not exceed the total benefits ensuing from the corresponding cooperative interaction. 5) Translators, insofar as they are more than simple messengers, are responsible for the capacity of their work to contribute to long-term stable, cross-cultural cooperation. Finally, the book ends with an afterword, which is a homage to those newly departed translation studies scholars that Pym has discussed in the book, namely Henri Meshonnic, Hans J. Vermeer, Peter Newmark and Eugene Nida.

Whereas the first five chapters are philosophical in nature, the $6^{\text {th }}$ chapter, Agents of cooperation, 
is practical. It covers professional issues such as how much translators should charge, the limits of their role, whose side they should be on (150), and how to calculate transaction costs (140148). The chapter should be interesting reading also for practicing translators, unlike the first five chapters, which, I suspect, might be too abstract and high-flown for other than translation studies scholars. In my personal opinion, the $6^{\text {th }}$ chapter is the most thought-provoking part in the book, although I would have wanted the author to also discuss the translating agent in more detail, within the framework of, for instance, actor-network theory, Bourdieu's sociology and/or agency theory. As it is, the conflicting interests of the various actors, translators, translation companies, clients and end-users are not visible, and this fact makes the cooperation model a rather optimistic one.

The methodology used by the author is based on cases, sometimes real, sometimes fictional (2), which are then combined with theoretical reviews of some scholars' works and ideas on ethics, including the author himself with 23 references to his own works. Regrettably, as the book is a translation of the French original based on lectures given in 1994, some more recent and interesting contributions regarding the subject at hand have not been included. Here I refer, among others, to Koskinen 2000, Tymoczko 2007 and 2009, Inghilleri 2009, and the 2011 special issue on ethics in The Interpreter and Translator Trainer edited by Baker/Maier. In any case, the author promises to break with the dilemma "between sociological empirism and the outpouring of presupposition - by working and reworking the extreme cases, pursuing their complexity, drawing out the human quandaries" (2). Generally, the argumentation is coherent and the approach successful and illuminating, but not always. When Pym reviews and criticizes, and at that he is unquestionably, and intimidatingly, talented, Schleiermacher, Nida, Newmark, Meshonnic, Spivak and even Venuti get a fair treatment.

One of the Translation Studies scholars, however, receives scathing criticism which contradicts what the author claims to have used as his methodology. Here I refer to the update "Mona Baker and the purity of the cause" in the $2^{\text {nd }}$ chapter titled Messengers. This update left me perplexed for five reasons. Firstly, because the update on Baker (57-60) begins with a lengthy, one and a half page discussion on the neo-Nazi leader and criminal Günter Deckert who has been imprisoned for Holocaust denial and racial hatred and whose case Pym had already introduced at the beginning of the chapter. Secondly, because the author attempts to make a link between Baker's and Deckert's activism, as if all activism is automatically suspicious and reprehensible. Thirdly, whereas, for instance, Eugene Nida's case receives an entire chapter - chapter 5 called Missionaries - comprising not less than 22 pages, Baker's case, or in fact only her activism, is briefly referred to and condemned on only one page. And yet the author points out in that same update that before one condemns anyone, one should first work through the complexities of the case (59, see also Walton 2003: 63 and Washbourne 2013: 45-46). Fourthly, although the author readily pardons Nida for his activism in spreading evangelism (110) and defends the Bible translation scholar's stance by pointing out that here we enter the non-negotiable (109), he does not accord Baker the same treatment. Instead, he reads Baker selectively based on two references only, of which one is an interview, reducing Baker and her many contributions to Translation Studies simply to her activism. And finally, and most alarmingly, the reader cannot but wonder whether the author does not want to see translators or translation scholars as social beings, "constructing and constructed subjects" in society (Wolf 2002: 33). As Salama-Carr (2007: 7) and Washbourne (2013: 40) remind us: there cannot be any translatorial ethics without the idea of the translator being also a social actor, not only an impartial observer.

If we overlook the above confusing update, the book is largely well-written. The style is typically that of Pym: occasionally rather eloquent, philosophical lingo, mixed up with nearly journalistic, entertaining and, in places, provocative and feisty language. Although the argumentation is for the most part convincing, the reader might be left wondering, here and there, how all the numerous, yet as such highly interesting details (particularly in the $2^{\text {nd }}$ chapter) combine to form the thread of the book. This is a point that the author himself makes, as he says that the method that he has 
used "can be confusing, since it risks losing itself in labyrinths in order to bring out the surprise of discovery" (11). As it is, one could claim that it might have been helpful to take the reader by the hand and pay more attention to the structuring of the new version. The updates and rewritten parts, although generally useful, might in fact interfere with the readability and coherence of the book.

Although the book lacks the most recent research in translatorial ethics, it is nevertheless thoughtprovoking reading for Translation Studies scholars and post-graduate students interested in ethics.

\section{References}

Baker, Mona/Maier, Carol (eds.) 2011: Ethics in Interpreter \& Translator Training: Critical Perspectives. The Interpreter and Translator Trainer (ITT); 5(1). Special Issue: Ethics and the Curriculum: Critical Perspectives.

Inghilleri, Moira 2009: Translators in War Zones: Ethics under Fire in Iraq. In Bielsa, Esperanza/Hughes, Christopher W. (eds.), Globalization, Political Violence and Translation. Basingstoke and New York: Palgrave MacMillan, 207-221.

Koskinen, Kaisa 2000: Beyond Ambivalence: Postmodernity and the Ethics of Translation. Tampere: University of Tampere. Also available at http://tampub.uta.fi/bitstream/handle/10024/67049/951-44-4941-X.pdf?sequence=1 .

Salama-Carr, Myriam 2007: Translating and Interpreting Conflict. Amsterdam/New York: Rodopi.

Tymoczko, Maria 2007: Enlarging Translation, Empowering Translators. Manchester: St. Jerome Publishing.

Tymoczko, Maria 2009: Translation, Ethics and Ideology. In Bielsa, Esperanza/Hughes, Christopher W. (eds.), Globalization, Political Violence and Translation. Basingstoke and New York: Palgrave MacMillan, 171-194.

Walton, Douglas 2003: Ethical Argumentation. Lanham, MD: Lexington Books.

Washbourne, Kelly 2013: Ethical Experts-in-training. In Kiraly, Don/Hansen-Schirra, Silvia/Maksymski, Karin (eds.), New Prospects and Perspectives for Educating Language Mediators. Tübingen: Narr Verlag, 35-52.

Wolf, Michaela 2002: Translation Activity between Culture, Society and the Individual: Towards a Sociology of Translation. In Harvey, K. (ed.), CTIS Occasional Papers 2. Manchester: UMIST, 33-43.

Kristiina Abdallah University of Vaasa, Finland 